EWA CIEŚLIK

Uniwersytet Ekonomiczny, Poznań

DOI : $10.14746 /$ rie.2016.10.18

\title{
Udział nowych państw członkowskich (UE-10) w globalnych lańcuchach wartości w pierwszych latach po akcesji do Unii Europejskiej ${ }^{1}$
}

\section{Wprowadzenie}

Chociaż liberalizacja handlu zagranicznego nie musi być czynnikiem sprzyjającym dynamizacji tempa rozwoju społecznego i ekonomicznego kraju spoza grupy gospodarek najwyżej zaawansowanych, jednak w przypadku nowych państw członkowskich $(\mathrm{UE}-10)^{2}$ intensyfikacja handlu przyczyniła się do zdynamizowania wzrostu i rozwoju ekonomicznego. Analizowane kraje zaprzestały koncentracji handlu zagranicznego na produktach pracochłonnych i surowcochłonnych na rzecz dóbr kapitałochłonnych i bardziej zaawansowanych technologicznie. Zaobserwowana tendencja powoduje, iż modele handlu zagranicznego prowadzone przez badane kraje coraz bardziej przypominają te obserwowane w wymianie handlowej w krajach UE-15. Ściślejsza integracja UE-10 ze strukturami unijnymi powoduje także wzrost zainteresowania zagranicznych inwestorów lokowaniem kapitałów w tym regionie.

Artykuł ma na celu ukazanie roli nowych państw członkowskich w globalnych łańcuchach wartości (GVCs) na tle procesów liberalizacyjnych i procesu integracji z Unią Europejską w pierwszych latach po akcesji. Przeprowadzone badanie ma na celu zweryfikowanie następującej hipotezy: pozycja nowych krajów członkowskich w globalnych łańcuchach wartości po akcesji do UE znacząco wzrosła. Badanie przeprowadzono na poziomie krajów i branż. W opracowaniu skoncentrowano się na analizie powiązań handlowych przed przystąpieniem do UE i kilka lat po akcesji. Stąd za okres badawczy przyjęto lata 2000-2009. W celu utrzymania jednolitości i porównywalności otrzymanych wyników badań w opracowaniu posłużono się bazami danych organizacji międzynarodowych, głównie OECD-WTO Trade in Value Added oraz World Input-Output Database.

\section{Nowe państwa czlonkowskie w GVCs: badanie na poziomie krajów}

Transformacja systemowa oraz stopniowa integracja gospodarek UE-10 z rynkami całej UE sprawiły, iż region stał się jednym z ogniw globalnych łańcuchów wartości (Dicken, et al., 2011). Istnieją trudności metodologiczne i wyzwania związane z okre-

${ }^{1}$ Artykuł stanowi rozszerzenie kwestii zaprezentowanych w opracowaniu (Cieślik 2015a).

${ }^{2} \mathrm{~W}$ artykule kraje należące do grupy UE-10 zamienne nazywane będą nowymi państwami członkowskimi oraz europejskimi krajami postsocjalistycznymi. 
śleniem miejsca kraju w GVCs. Jedną z przyczyn tych problemów jest brak zunifikowanej metody mierzenia wartości dodanej oraz często brak najnowszych danych dotyczących przepływów wartości dodanej w wymianie międzynarodowej. Podejmując próbę umiejscowienia krajów UE-10 w sieciach wartości należy przeanalizować wartości dodane w obrotach handlowych. Jednak takie uproszczone podejście nie zawsze udziela pełnej odpowiedzi dotyczącej umiejscowienia kraju w GVCs (Cieślik, 2015a). Bardziej kompleksową metodą pomiaru udziału państw postsocjalistycznych w GVCs jest przeprowadzenie dekompozycji wartości dodanej w eksporcie brutto, a następnie określenie zagranicznej wartości dodanej zawartej w całkowitym krajowym eksporcie brutto oraz krajowej wartości dodanej zawartej w eksporcie partnerów handlowych analizowanego państwa. Przyjęta metodyka została opracowana przez ekspertów z National Bureau of Economic Research (Koopman, et al., 2010). Powyższe wskaźniki charakteryzują pozycję kraju w ramach powiązań typu downstream lub upstream w GVCs. Wyższa wartość krajowej wartości dodanej zawartej w eksporcie partnerów handlowych badanego kraju świadczy o bardziej zaawansowanej pozycji państwa w GVCs, czyli przemieszczaniu się kraju w kierunku rynków upstream. Natomiast wraz z rosnącą wartością udziału zagranicznej wartości dodanej ucieleśnionej w całkowitym krajowym eksporcie należy spodziewać się spadku pozycji państwa w GVCs, czyli obserwuje się przesunięcie kraju w kierunku segmentu downstream. Do analizy dekompozycji wartości dodanej poza krajami UE-10 włączono także EU-27, USA, Japonię i Chiny, jako ważne ogniwa GVCs33.

Wyniki badania dekompozycji wartości dodanej wskazuja, iż udziały zagranicznej wartości dodanej zawartej w eksporcie krajowym analizowanych państw pozostawały zróżnicowane. Najwyższy wskaźnik zagranicznej wartości dodanej ucieleśnionej w krajowym eksporcie cechował w 2009 r. Słowację (ponad 44\%), najniższy - Rumunię (24\%). Polskę można zaliczyć do krajów o raczej niskiej zagranicznej wartości dodanej ucieleśnionej w eksporcie (prawie 28\%) na tle pozostałych państw UE-10. Jednak wszystkie kraje postsocjalistyczne odbiegały od średniej unijnej oraz wartości mierników osiagniętych przez USA czy Japonię. Pozytywną tendencję obserwuje się natomiast w przypadku udziału krajowej wartości dodanej zawartej w eksporcie partnerów handlowych UE-10. Większość z badanych państw osiagało w 2009 r. wartość miernika przekraczającą średnią unijną, jednak wielkości te odbiegały nadal od poziomu amerykańskiego czy japońskiego. Szczególnie wysoką krajową wartością dodaną w eksporcie swoich partnerów handlowych cechowały się w 2009 r. Łotwa i Czechy, odpowiednio 29,8\% i 22,2\%. Także Polska nieznacznie przekroczyła średnią UE-27. $\mathrm{W}$ analizowanych krajach obserwuje się także wysoki stopień partycypacji w GVCs oraz spore znaczenie w gospodarce narodowej udziału w GVCs (tabela 1).

Faktycznie otrzymane wyniki świadczą o dwukierunkowych powiązaniach badanych krajów w ramach specjalizacji wertykalnej, chociaż z silniejszą tendencją do zajmowania niższych pozycji w GVCs względem krajów rozwiniętych, szczególnie

3 Jednak w porównaniach UE-10 z dużymi gospodarkami światowymi należy zachować ostrożność w interpretacji, gdyż naturalnym jest, iż duże gospodarki charakteryzują się wysokim wskaźnikiem samowystarczalności. Stąd zagraniczna wartość dodana ucieleśniona w ich eksporcie jest znacznie niższa niż w przypadku mniejszych krajów o znacznie słabiej rozwiniętych rynkach wewnętrznych. 
w bardziej zaawansowanych technologicznie sektorach gospodarki. $Z$ jednej strony obserwujemy znaczący udział państw postsocjalistycznych w segmencie downstream w relacji do krajów rozwiniętych, czyli są one importerami zagranicznej wartości dodanej, którą następnie zawierają w krajowym eksporcie. Jednak zbliżony do średniej unijnej udział wartości dodanej UE-10 w zagranicznym eksporcie świadczy także o stopniowym wchodzeniu badanych państw do segmentu upstream względem krajów trzecich.

O większej sile powiązań typu downstream świadczy współczynnik relatywnej pozycji kraju w GVCs. Im miernik osiąga wyższe wartości, tym kraj plasuje się na wyższych szczeblach w ramach GVCs. Wartością graniczną pomiędzy segmentami upstream i downstream jest 1 . W rezultacie w porównaniu z USA i Japonią, a nawet średnią unijną badane kraje stanowią niższe ogniwa GVCs. W 2000 r. jedynym państwem, które wkroczyło do rynków upstream była Łotwa, a Polska znalazła się na granicy. Jednak do 2009 r. oba kraje pogorszyły swoje pozycje w łańcuchu wartości. Tendencję spadkową w relatywnej pozycji w GVCs obserwuje się w większości UE-10. Jedynie Czechy, Estonia, Węgry i Rumunia nieznacznie poprawiły swoją lokatę (rysunek 1).

Tabela 1

Stopień udziału wybranych krajów w GVCs w latach 2000 i 2009 (w \%)

\begin{tabular}{|l|c|c|c|c|c|c|c|}
\hline & \multicolumn{2}{|c|}{$\begin{array}{c}\text { Zagraniczna wartość } \\
\text { dodana zawarta w calko- } \\
\text { witym eksporcie kraju }\end{array}$} & \multicolumn{2}{|l|}{$\begin{array}{l}\text { Krajowa wartość doda- } \\
\text { na zawarta w eksporcie } \\
\text { partnerów handlowych }\end{array}$} & \multicolumn{2}{|c|}{$\begin{array}{c}\text { Stopień } \\
\text { partycypacji } \\
\text { w GVCs }\end{array}$} & $\begin{array}{c}\text { Znaczenie udziału } \\
\text { w GVCs w gospo- } \\
\text { darce narodowej } \\
\text { (\% PKB) }\end{array}$ \\
\cline { 2 - 9 } & $\mathbf{2 0 0 0}$ & $\mathbf{2 0 0 9}$ & $\mathbf{2 0 0 0}$ & $\mathbf{2 0 0 9}$ & $\mathbf{2 0 0 0}$ & $\mathbf{2 0 0 9}$ & $\mathbf{2 0 0 9}$ \\
\hline Czechy & 39,18 & 39,39 & 22,2 & 23,0 & 61,38 & 62,39 & 25,80 \\
\hline Estonia & 50,06 & 33,22 & 18,7 & 21,3 & 68,76 & 54,52 & 24,85 \\
\hline Węgry & 46,19 & 39,91 & 17,2 & 18,7 & 63,39 & 58,61 & 25,40 \\
\hline Polska & 23,33 & 27,89 & 24,1 & 20,5 & 47,43 & 48,39 & 10,84 \\
\hline Słowacja & 48,26 & 44,35 & 21,2 & 17,9 & 69,46 & 62,25 & 30,77 \\
\hline Słowenia & 37,52 & 34,40 & 20,6 & 18,2 & 58,12 & 52,60 & 26,15 \\
\hline Bułgaria & 38,13 & 32,14 & 20,2 & 15,7 & 58,33 & 47,84 & 15,35 \\
\hline Lotwa & 24,62 & 25,18 & 29,8 & 24,3 & 54,42 & 49,48 & 10,69 \\
\hline Litwa & 32,56 & 36,05 & 17,7 & 14,1 & 50,26 & 50,15 & 26,00 \\
\hline Rumunia & 27,39 & 24,18 & 20,8 & 21,9 & 48,19 & 46,08 & 13,32 \\
\hline EU-27 & 12,63 & 13,62 & 18,0 & 17,8 & 30,63 & 31,42 & 4,29 \\
\hline Chiny & 18,81 & 32,63 & 13,8 & 13,4 & 32,61 & 46,03 & 11,84 \\
\hline Niemcy & 24,40 & 26,64 & 24,4 & 22,8 & 48,80 & 49,44 & 17,34 \\
\hline USA & 8,88 & 11,29 & 31,1 & 28,5 & 39,98 & 39,79 & 4,02 \\
\hline Japonia & 9,91 & 14,79 & 26,1 & 33,0 & 36,01 & 47,79 & 5,87 \\
\hline
\end{tabular}

Krajowa wartość dodana zawarta w eksporcie partnerów handlowych obliczona na podstawie wskaźników partycypacji OECD-WTO.

Stopień partycypacji w GVCs mierzony jest udziałem sumy krajowej wartości dodanej zawartej w eksporcie partnerów handlowych i zagranicznej wartości dodanej w eksporcie brutto analizowanego kraju.

Źródło: Obliczenia własne na podstawie danych TiVA OECD-WTO. 


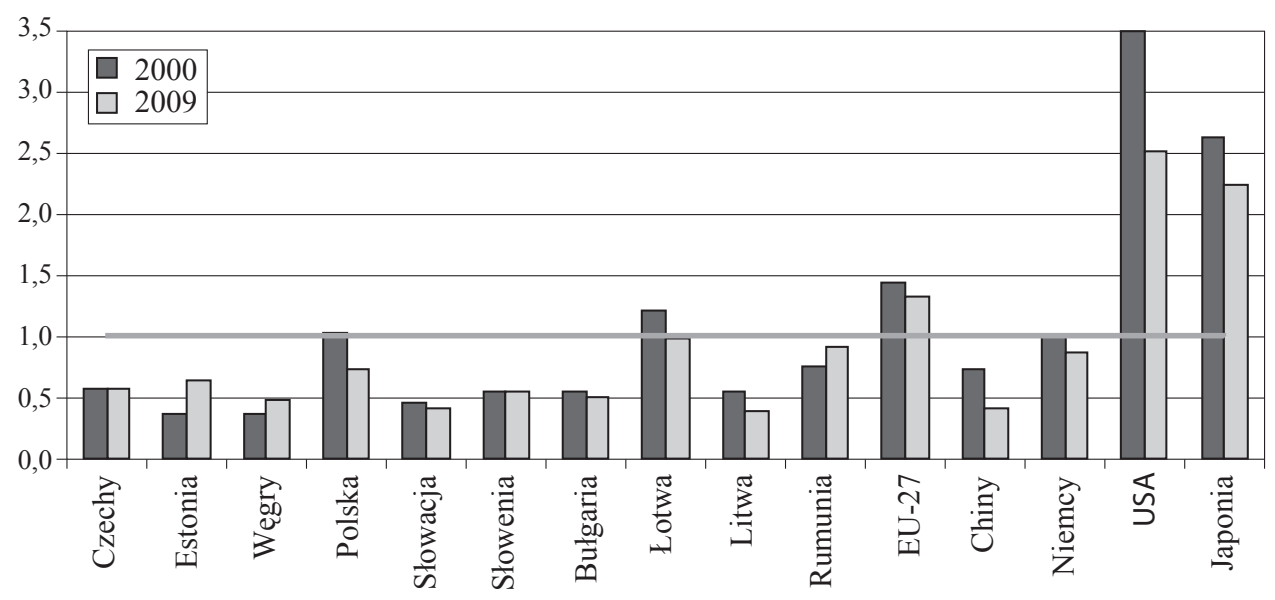

Rys. 1. Relatywna pozycja wybranych krajów w GVCs w latach 2000 i 2009

Pozycja obliczona na podstawie relatywnego współczynnika pozycji w GVCs, liczonego jako relacja krajowej wartości dodanej zawartej w eksporcie partnerów handlowych do zagranicznej wartości dodanej zawartej w eksporcie krajowym.

Wartość 1 stanowi granicę między wyższymi a niższymi ogniwami GVCs.

Źródło: Obliczenia własne na podstawie danych TiVA OECD-WTO.

Chcąc ukazać pięć krajów tworzących najwyższy odsetek eksportu brutto UE-10 należy wskazać na: Rosję (15,21\%), Niemcy (14,02\%), USA (5,97\%), Włochy (5,68\%) i Francję $(4,74 \%)$. Rosja pozostawała nadrzędnym partnerem w łańcuchach wartości dla jej najbliższych sąsiadów. Szczególnie ścisłe powiązania w tym zakresie występują z Litwą, gdzie około połowy zagranicznej wartości dodanej realizowały firmy rosyjskie, głównie w sektorze chemicznym i niemetalowych produktów mineralnych. Niemcy były najważniejszym partnerem dla Czech, Węgier i Polski, przede wszystkim w zakresie wartości dodanej w przemyśle motoryzacyjnym. Ogromną część eksportu UE-10 cechuje ścisłe powiązanie z produkcją i GVCs w Europie Zachodniej. Zjawisko to jest szczególnie widoczne w przypadku Słowacji, Czech, Polski, Słowenii oraz Węgier. W tych państwach ponad $40 \%$ zagranicznej wartości dodanej ucieleśnionej w eksporcie pochodzi z krajów UE-15. W przypadku krajów bałtyckich, szczególnie Litwy, powiązania eksportu z zachodnioeuropejskimi łańcuchami wartości są znacznie słabsze. Przykładowo, Litwa bardziej powiązała swój eksport i jego wartość dodaną z rosyjskimi łańcuchami wartości i rynkami azjatyckimi (tabela 2).

Tabela 2

Udział zagranicznej wartości dodanej wybranych krajów w eksporcie brutto UE-10 w 2009 r. (w \%)

\begin{tabular}{||c|c|c|c|c|c|c|c|c|c|c||}
\hline & Czechy & Estonia & Węgry & Polska & Słowacja & Slowenia & Bułgaria & Lotwa & Litwa & Rumunia \\
\hline 1 & 2 & 3 & 4 & 5 & 6 & 7 & 8 & 9 & 10 & 11 \\
\hline Austria & 2,6 & 0,7 & 4,0 & 1,9 & 2,3 & 5,8 & 1,7 & 1,0 & 0,5 & 3,0 \\
\hline Belgia & 1,7 & 1,2 & 1,4 & 1,9 & 1,2 & 1,4 & 1,1 & 1,1 & 0,9 & 1,5 \\
\hline Czechy & 0,0 & 0,6 & 1,9 & 2,7 & 6,9 & 1,9 & 0,9 & 0,8 & 0,8 & 1,5 \\
\hline
\end{tabular}




\begin{tabular}{|c|c|c|c|c|c|c|c|c|c|c|}
\hline 1 & 2 & 3 & 4 & 5 & 6 & 7 & 8 & 9 & 10 & 11 \\
\hline Estonia & 0,0 & 0,0 & 0,0 & 0,1 & 0,0 & 0,0 & 0,0 & 3,5 & 0,7 & 0,0 \\
\hline Finlandia & 0,5 & 5,7 & 0,5 & 1,1 & 0,4 & 0,4 & 0,3 & 2,0 & 0,8 & 0,4 \\
\hline Francja & 4,3 & 4,2 & 4,9 & 4,9 & 5,3 & 6,4 & 3,8 & 4,4 & 2,8 & 6,4 \\
\hline Niemcy & 21,4 & 9,5 & 20,8 & 18,7 & 16,4 & 14,0 & 8,2 & 10,8 & 6,8 & 13,6 \\
\hline Węgry & 1,4 & 0,2 & 0,0 & 1,1 & 1,9 & 1,3 & 0,7 & 0,6 & 0,2 & 4,2 \\
\hline Włochy & 4,7 & 2,4 & 4,4 & 7,3 & 4,8 & 11,8 & 5,7 & 2,6 & 2,0 & 11,1 \\
\hline Japonia & 5,0 & 4,4 & 4,5 & 3,1 & 3,5 & 3,3 & 3,4 & 3,5 & 2,1 & 2,3 \\
\hline Korea Pd. & 2,0 & 1,8 & 3,0 & 2,6 & 6,5 & 1,3 & 1,1 & 0,7 & 0,6 & 1,3 \\
\hline Holandia & 2,7 & 1,9 & 3,4 & 2,8 & 1,4 & 2,0 & 1,4 & 2,0 & 1,3 & 2,3 \\
\hline Norwegia & 1,1 & 1,8 & 0,5 & 1,3 & 0,5 & 0,7 & 0,4 & 1,7 & 0,6 & 0,6 \\
\hline Polska & 5,2 & 2,0 & 2,2 & 0,0 & 3,3 & 1,5 & 1,3 & 4,4 & 3,6 & 2,2 \\
\hline Portugalia & 0,3 & 0,2 & 0,2 & 0,3 & 0,2 & 0,2 & 0,3 & 0,2 & 0,1 & 0,4 \\
\hline Słowacja & 3,3 & 0,2 & 2,2 & 1,5 & 0,0 & 1,3 & 0,4 & 0,5 & 0,3 & 1,0 \\
\hline Słowenia & 0,4 & 0,1 & 0,4 & 0,3 & 0,3 & 0,0 & 0,3 & 0,2 & 0,1 & 0,4 \\
\hline Hiszpania & 2,1 & 1,0 & 1,6 & 2,1 & 1,6 & 2,6 & 1,5 & 1,1 & 0,6 & 1,9 \\
\hline Szwecja & 1,1 & 4,9 & 1,1 & 1,8 & 0,8 & 1,2 & 0,9 & 3,3 & 1,5 & 0,9 \\
\hline Szwajcaria & 1,5 & 1,0 & 1,3 & 1,4 & 1,1 & 1,7 & 1,2 & 1,4 & 0,5 & 1,4 \\
\hline \begin{tabular}{|l} 
Wielka \\
Brytania
\end{tabular} & 3,2 & 2,2 & 3,1 & 3,5 & 3,9 & 1,7 & 1,7 & 1,9 & 1,0 & 3,2 \\
\hline USA & 5,4 & 7,4 & 7,6 & 6,1 & 4,4 & 5,8 & 5,5 & 7,8 & 4,7 & 5,0 \\
\hline Chiny & 6,2 & 4,1 & 5,8 & 4,6 & 3,7 & 3,4 & 3,9 & 3,3 & 2,5 & 3,4 \\
\hline Eotwa & 0,1 & 2,5 & 0,0 & 0,1 & 0,0 & 0,0 & 0,0 & 0,0 & 1,8 & 0,0 \\
\hline Litwa & 0,1 & 4,0 & 0,1 & 0,4 & 0,1 & 0,1 & 0,1 & 9,1 & 0,0 & 0,0 \\
\hline Rumunia & 0,6 & 0,1 & 2,1 & 0,5 & 0,5 & 1,0 & 2,9 & 0,2 & 0,1 & 0,0 \\
\hline Rosja & 7,5 & 15,7 & 6,8 & 11,4 & 14,8 & 4,8 & 17,6 & 15,5 & 50,0 & 8,0 \\
\hline $\begin{array}{l}\text { Reszta } \\
\text { świata }\end{array}$ & 13,00 & 17,30 & 13,40 & 12,70 & 11,70 & 21,00 & 24,50 & 13,40 & 10,80 & 17,00 \\
\hline \begin{tabular}{|l} 
Razem \\
Europa \\
Zachodnia
\end{tabular} & 48,90 & 38,60 & 49,00 & 51,20 & 41,50 & 52,00 & 33,80 & 35,80 & 21,10 & 49,50 \\
\hline
\end{tabular}

Źródło: Obliczenia własne na podstawie danych (World Input-Output Database, 2015).

Chociaż UE-10 w znacznej mierze opierają swój eksport na wartości dodanej pochodzącej z krajów Europy Zachodniej oraz innych wysoko rozwiniętych gospodarek, to odwrotne zjawisko nie występuje. Wartość dodana pochodząca z UE-10 w niewielkim stopniu znalazła wykorzystanie w strumieniach eksportu innych krajów. Najwyższe wskaźniki korzystania z wartości dodanej z UE-10 obserwowano w przypadku Niemiec (prawie 9\%), Austrii (8,9\%) i Rosji (7,7\%) (tabela 3). W niemieckim eksporcie brutto najwięcej wartości dodanej z UE-10 występowało w branżach samochodowej, metali podstawowych i produktach przemysłu metalurgicznego oraz chemicznego. Wartość dodana kierowana do Niemiec pochodziła głównie z Polski i Czech. Austria współpracuje przede wszystkim z Czechami w zakresie wartości dodanej przemysłu maszynowego oraz metali podstawowych i wyrobów metalurgicznych. Rosyjski eksport powiązany jest $\mathrm{w}$ znacznej mierze $\mathrm{z}$ wartością dodaną pochodzącą z Polski i Czech w zakresie metali podstawowych i produktach przemysłu metalurgicznego oraz chemicznego. 
Tabela 3

Udział wartości dodanej pochodzącej z UE-10 w zagranicznej wartości dodanej ucieleśnionej w eksporcie brutto wybranych krajów i regionów w 2009 r. (w \%)

\begin{tabular}{|l|c|c|c|c|c|c|c|c|c|c|c||}
\hline & Czechy & Estonia & Węgry & Polska & $\begin{array}{c}\text { Stowa- } \\
\text { cja }\end{array}$ & $\begin{array}{c}\text { Słowe- } \\
\text { nia }\end{array}$ & $\begin{array}{c}\text { Bul- } \\
\text { garia }\end{array}$ & Lotwa & Litwa & $\begin{array}{c}\text { Ru- } \\
\text { munia }\end{array}$ & $\begin{array}{c}\text { Razem } \\
\text { UE-10 }\end{array}$ \\
\hline Austria & 2,63 & 0,04 & 1,60 & 1,68 & 1,38 & 0,84 & 0,12 & 0,04 & 0,05 & 0,52 & 8,89 \\
\hline Belgia & 0,86 & 0,06 & 0,41 & 0,90 & 0,29 & 0,12 & 0,24 & 0,09 & 0,08 & 0,35 & 3,39 \\
\hline Dania & 0,90 & 0,24 & 0,47 & 1,80 & 0,22 & 0,15 & 0,16 & 0,26 & 0,34 & 0,39 & 4,92 \\
\hline Finlandia & 0,64 & 1,29 & 0,28 & 1,21 & 0,22 & 0,11 & 0,08 & 0,24 & 0,19 & 0,19 & 4,45 \\
\hline Francja & 0,88 & 0,05 & 0,42 & 1,16 & 0,28 & 0,27 & 0,10 & 0,06 & 0,09 & 0,50 & 3,81 \\
\hline Niemcy & 2,59 & 0,07 & 1,16 & 3,02 & 0,85 & 0,38 & 0,14 & 0,08 & 0,05 & 0,62 & 8,96 \\
\hline Irlandia & 0,18 & 0,04 & 0,23 & 0,58 & 0,07 & 0,03 & 0,04 & 0,04 & 0,04 & 0,08 & 1,33 \\
\hline Włochy & 0,94 & 0,04 & 0,69 & 1,62 & 0,44 & 0,43 & 0,29 & 0,05 & 0,06 & 0,91 & 5,47 \\
\hline Japonia & 0,19 & 0,04 & 0,20 & 0,26 & 0,11 & 0,05 & 0,04 & 0,03 & 0,03 & 0,09 & 1,04 \\
\hline Holandia & 0,58 & 0,14 & 0,34 & 0,78 & 0,16 & 0,06 & 0,08 & 0,06 & 0,08 & 0,21 & 2,48 \\
\hline Norwegia & 0,80 & 0,32 & 0,29 & 2,06 & 0,22 & 0,09 & 0,10 & 0,27 & 0,44 & 0,33 & 4,91 \\
\hline Portugalia & 0,62 & 0,04 & 0,44 & 0,75 & 0,17 & 0,10 & 0,09 & 0,03 & 0,07 & 0,41 & 2,72 \\
\hline Hiszpania & 0,81 & 0,09 & 0,63 & 1,02 & 0,21 & 0,15 & 0,17 & 0,11 & 0,10 & 0,50 & 3,78 \\
\hline Szwecja & 0,88 & 0,37 & 0,38 & 2,27 & 0,31 & 0,08 & 0,14 & 0,48 & 0,27 & 0,23 & 5,39 \\
\hline Wielka & 0,70 & 0,07 & 0,50 & 1,13 & 0,20 & 0,09 & 0,09 & 0,14 & 0,10 & 0,30 & 3,31 \\
Brytania & & & & & & & & & & & \\
\hline USA & 0,22 & 0,05 & 0,20 & 0,31 & 0,09 & 0,05 & 0,05 & 0,04 & 0,05 & 0,13 & 1,19 \\
\hline Chiny & 0,25 & 0,03 & 0,24 & 0,37 & 0,10 & 0,04 & 0,04 & 0,03 & 0,02 & 0,12 & 1,25 \\
\hline Rosja & 1,67 & 0,22 & 0,93 & 1,96 & 1,06 & 0,37 & 0,27 & 0,19 & 0,39 & 0,60 & 7,65 \\
\hline
\end{tabular}

Źródło: Obliczenia własne na podstawie danych (World Input-Output Database, 2015).

Jeżeli analizować wartość dodaną w przypływach handlowych na linii UE-10 i świat pojawiają się trzy zasadnicze zjawiska, które wystąpiły w pierwszych latach po akcesji. Po pierwsze, napływy wartości dodanej pochodzącej z krajów Zachodu do UE-10 przewyższa odwrotny kierunek przepływów - napływ wartości dodanej wytworzonej w tych ostatnich. Po drugie, taki przepływ wartości dodanej wyraźnie określa pozycje UE-10 i Europy Zachodniej w łańcuchach wartości, czyli te ostatnie zajmują wyższe pozycje w GVCs. Po trzecie, wysoki udział wartości dodanej pochodzącej z krajów Europy Zachodniej w eksporcie UE-10 wskazuje na ścisłe powiązania eksportu tych ostatnich $\mathrm{z}$ łańcuchami produkcji Europy Zachodniej. Jednocześnie kraje zachodnioeuropejskie ze znacznie mniejszą intensyfikacją importują z UE-10 komponenty niezbędne do ich produkcji na eksport.

\section{Nowe państwa czlonkowskie w GVCs: badanie na poziomie branż}

Można spróbować scharakteryzować kraje UE-10 w zależności od zajmowanego przez nie miejsca w GVCs w danej branży. W badaniu uwzględniono najbardziej zinternacjonalizowane sektory: transportowy i elektroniczny, jednocześnie uznając je za branże o średnim i wysokim zaawansowaniu technologicznym zgodnie z klasyfikacjami OECD. Poza wymienionymi sektorami, do analizy włączono sektor wydobywczy i metalurgiczny, ponieważ udział tych sektorów w produkcji przemysłowej UE-10 jest 
relatywnie wysoki. Ponadto w badaniu wzięto pod uwagę sektor produkcji żywności i napojów, które pozostają ważną pozycją w wybranych gospodarkach regionu Europy Środkowo-Wschodniej, w tym Polsce.

Rozwój branż środków transportu oraz elektroniki w europejskich krajach postsocjalistycznych może wskazywać na zaawansowanie tych gospodarek. Wydajność pracy w tych sektorach rośnie najszybciej. Ponadto gałąz motoryzacyjna stała się jedną z głównych sił napędowych dla eksportu wielu UE-10 oraz przyciagnęła znaczne BIZ do omawianych państw. Jednocześnie należy mieć na względzie, iż w praktyce branża środków transportu bardziej skoncentrowana jest na montażu sprowadzonych części samochodowych niż na ich produkcji od postaw. Biorąc pod uwagę wskaźniki określające pozycję w GVCs w 2009 r., pięć państw (Czechy, Rumunia, Węgry, Słowacja i Polska) znalazło się w górnej części łańcucha wartości. Sektor motoryzacyjny w wymienionych krajach stanowi ważny filar gospodarek, co także po części tłumaczy wysoką ich pozycję w GVCs podczas, gdy kraje bałtyckie, Słowenia i Bułgaria nie posiadają równie długich tradycji w zakresie produkcji środków transportu. Stąd znajdują się na znacznie niższych pozycjach w ramach GVCs (schemat 1).

Elektronika stanowi domenę eksportu gospodarek „tygrysów azjatyckich” oraz innych państw najwyżej zaawansowanych rozwojowo. Kraje te osiagają wysokie wskaźniki przewagi komparatywnej w tej branży i znacznie przewyższają europejskie państwa postsocjalistyczne $\mathrm{w}$ zakresie zaawansowania technologicznego. $\mathrm{Z}$ analizowanych państw Węgry i Czechy uplasowały się na najwyższych pozycjach w zakresie GVCs obejmujących elektronikę, jednak ich pozycja znacznie odbiega od liderów tego łańcucha wartości (schemat 1).

W przypadku przemysłu wydobywczego prawie wszystkie badane europejskie kraje postsocjalistyczne, poza Węrami i Słowenią, znajdują się w segmencie upstream, jednak nie dorównują światowym potęgom wydobywczym, takim jak Arabia Saudyjska, Rosja, czy Chile. Ciekawym przypadkiem są Węgry, w których udział przemysłu wydobywczego w PKB jest stosunkowo wysoki, jednak wskaźniki GVCs plasują kraj na dalekiej pozycji w segmencie downstream. Taką lokatę w łańcuchu wartości można próbować wytłumaczyć relatywnie wysokimi udziałami zagranicznej wartości dodanej w eksporcie brutto produktów tego sektora. Dodatkowo branża wydobywcza na Węgrzech eksportuje niewielką część swoich wyrobów (najmniej spośród wszystkich UE-10). Wysoki udział zagranicznej wartości dodanej stanowi konsekwencję znaczących w porównaniu z pozostałymi krajami UE-10 napływów BIZ do sektora wydobywczego na Węgrzech (schemat 1).

Przemysł metalurgiczny cechuje się długimi tradycjami w krajach postsocjalistycznych i wynika z dobrego wyposażenia tych krajów w niezbędne dla tej branży surowce. W wielu państwach ustanowiono nawet specjalne „klastry produkcji metalurgicznej" (schemat 1).

Z kolei sektor produkcji żywności i napojów plasuje Polskę i Rumunię na wysokich pozycjach w GVCs. Te dwa kraje posiadają korzystną pozycję geograficzną, aby stać się ważnymi światowymi producentami żywności oraz przekształcić się (szczególnie Polska) w regionalne centrum produkcji dóbr żywnościowych. McKinsey oszacował, iż w prawie wszystkich rodzajach wytwarzanych produktów żywnościowych w krajach UE-10, oszczędności wynikające z siły roboczej, surowców i materiałów oraz 
pozostałych kosztów importowanych produktów do Europy Zachodniej, przewyższają koszty transportu (McKinsey, 2013) (schemat 1).

Schemat 1. UE-10 w GVCs w zakresie wybranych branż (dane na 2009 r.)

\begin{tabular}{|c|c|c|c|c|c|}
\hline & $\begin{array}{c}\text { Środki } \\
\text { transportu }\end{array}$ & Elektronika & $\begin{array}{c}\text { Przemysł } \\
\text { wydobywczy }\end{array}$ & $\begin{array}{c}\text { Przemysl } \\
\text { metalurgiczny }\end{array}$ & $\begin{array}{l}\text { Żywność } \\
\text { i napoje }\end{array}$ \\
\hline $\begin{array}{r}\vdots \\
\vdots \\
\vdots \\
\vdots \\
\vdots \\
\vdots \\
\Sigma\end{array}$ & $\begin{array}{l}\text { Japonia }(14) \\
\text { USA }(5,9) \\
\text { Czechy }(\mathbf{5 , 6 )} \\
\text { Rumunia }(\mathbf{3 , 9 )} \\
\text { Węgry }(\mathbf{3 , 8 )} \\
\text { Niemcy }(3,7) \\
\text { Korea Południo- } \\
\text { wa }(3,4) \\
\text { Słowacja }(\mathbf{3 , 1}) \\
\text { Polska }(\mathbf{2 , 8 )} \\
\text { Włochy }(2,7) \\
\text {......... }\end{array}$ & 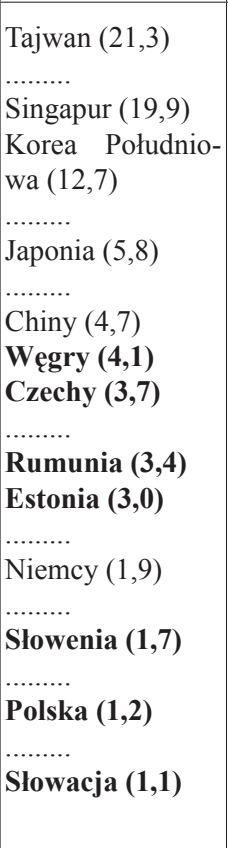 & 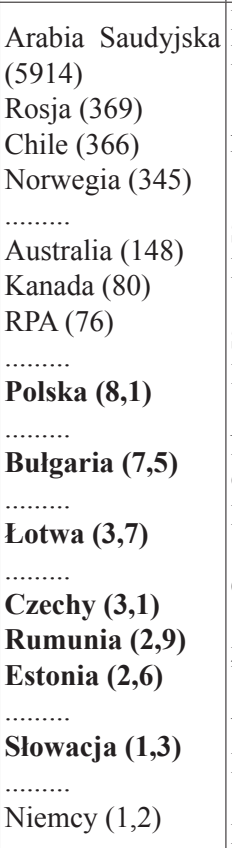 & 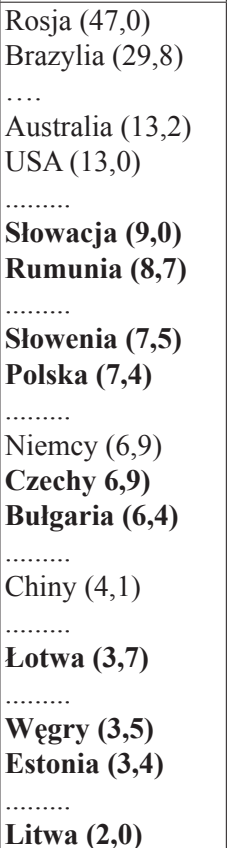 & $\begin{array}{l}\text { Australia }(18,0) \\
\ldots \ldots \ldots . . . \\
\text { Rumunia }(\mathbf{2 , 1}) \\
\ldots \ldots \ldots . . . \\
\text { Polska }(\mathbf{1}, \mathbf{3}) \\
\text { USA }(1,3) \\
\ldots \ldots \ldots . . . \\
\text { Francja }(1,1)\end{array}$ \\
\hline 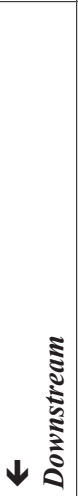 & $\begin{array}{l}\text { Chiny }(0,9) \\
\ldots \ldots \ldots . . \\
\text { Slowenia }(\mathbf{0 , 6}) \\
\ldots \ldots \ldots . \\
\text { Estonia }(\mathbf{0 , 3}) \\
\ldots \ldots \ldots . \\
\text { Lotwa }(\mathbf{0 , 2}) \\
\ldots \ldots \ldots . . \\
\text { Litwa }(\mathbf{0 , 0 6}) \\
\ldots \ldots \ldots . \\
\text { Bulgaria }(\mathbf{0 , 0 1}) \\
\ldots \ldots \ldots . .\end{array}$ & $\begin{array}{l}\text { Bulgaria }(\mathbf{0 , 7}) \\
\ldots \ldots \ldots \\
\text { Litwa }(\mathbf{0 , 5}) \\
\ldots \ldots \ldots . . . \\
\text { Lotwa }(\mathbf{0 , 4}) \\
\ldots \ldots \ldots . \\
\text { Argentyna }(0,3) \\
\ldots \ldots \ldots . . .\end{array}$ & $\begin{array}{l}\text { Korea Południo- } \\
\text { wa }(0,88) \\
\text { Francja }(0,73) \\
\ldots \ldots \ldots . . \\
\text { Słowenia }(\mathbf{0 , 6 )} \\
\ldots \ldots \ldots . \\
\text { Węgry }(\mathbf{0 , 2}) \\
\ldots \ldots \ldots .\end{array}$ & $\begin{array}{l}\text { Filipiny }(0,8) \\
\text { Singapur }(0,7) \\
\ldots \ldots \ldots . . \\
\text { Arabia Saudyjska } \\
(0,2) \\
\ldots \ldots \ldots .\end{array}$ & $\begin{array}{l}\text { Litwa }(\mathbf{0 , 9 )} \\
\text { Lotwa }(\mathbf{0 , 8}) \\
\ldots \ldots \ldots . . . \\
\text { Słowacja }(\mathbf{0 , 6 )} \\
\text { Estonia }(\mathbf{0 , 6 )} \\
\text { Słowenia }(\mathbf{0 , 5}) \\
\ldots \ldots \ldots . . \\
\text { Czechy }(\mathbf{0 , 5}) \\
\text { Niemcy }(0,5) \\
\ldots \ldots \ldots . . . \\
\text { Bułgaria }(\mathbf{0 , 4}) \\
\ldots \ldots \ldots . . \\
\text { Węgry }(\mathbf{0 , 3}) \\
\text {......... }\end{array}$ \\
\hline
\end{tabular}

Źródło: Obliczenia własne na podstawie danych TiVA OECD-WTO.

Warto zwrócić uwagę na zmiany w pozycjach UE-10 w GVC przed i po akcesji do struktur unijnych. Okazuje się, iż w przypadku produktów żywnościowych i napojów pozycja prawie wszystkich analizowanych państw (z wyjątkiem Polski) pogorszyła się. Odwrotną tendencję można zauważyć w przypadku przemysłu metalurgicznego, gdzie tylko Łotwa po akcesji do UE nieznacznie przesunęła się w dół w ramach GVCs. W zakresie środków transportu kraje takie jak Czechy, Węgry, Polska i Słowacja nadal 
utrzymywały się w GVCs w ramach powiązań upstream. Znaczną poprawę w relatywnej pozycji w tej branży zanotowała Rumunia, która zauważalnie przesunęła się w górę w łańcuchach wartości. Pozostałe kraje nieznacznie zmieniły swoje miejsce w tej branży. Elektronika krajów UE-10 mocno ucierpiała na akcesji do UE, ponieważ poza Czechami, Estonią i Węgrami, żaden z krajów nie poprawił swojej pozycji w GVCs ${ }^{4}$. Reakcja przemysłu wydobywczego na akcesję do UE okazała się zróżnicowana w zależności od kraju. W większości państw UE-10 zaobserwowano poprawę w ramach powiązań upstream. Natomiast Polska i Rumunia znacząco pogorszyły swoją pozycję, a Słowenia zachowała miejsce sprzed akcesji (tabela 4).

Tabela 4

Zmiany w relatywnej pozycji UE-10 w GVCs w latach 2000 i 2009

\begin{tabular}{||l|c|c|c|c|c|c|c|c|c|c|}
\hline & \multicolumn{2}{|c|}{$\begin{array}{c}\text { Srodki } \\
\text { transportu }\end{array}$} & \multicolumn{2}{|c|}{ Elektronika } & \multicolumn{2}{c|}{$\begin{array}{c}\text { Przemysl } \\
\text { wydobywczy }\end{array}$} & \multicolumn{2}{c|}{$\begin{array}{c}\text { Przemysl } \\
\text { metalurgiczny }\end{array}$} & $\begin{array}{c}\text { Produkty żywno- } \\
\text { ściowe i napoje }\end{array}$ \\
\hline & $\mathbf{2 0 0 0}$ & $\mathbf{2 0 0 9}$ & $\mathbf{2 0 0 0}$ & $\mathbf{2 0 0 9}$ & $\mathbf{2 0 0 0}$ & $\mathbf{2 0 0 9}$ & $\mathbf{2 0 0 0}$ & $\mathbf{2 0 0 9}$ & $\mathbf{2 0 0 0}$ & $\mathbf{2 0 0 9}$ \\
\hline Czechy & 1,8 & $\mathbf{5 , 6}$ & 3,1 & $\mathbf{3 , 7}$ & 2,0 & $\mathbf{3 , 1}$ & 6,2 & $\mathbf{6 , 9}$ & 0,6 & 0,5 \\
\hline Estonia & 0,3 & 0,3 & 2,2 & $\mathbf{3 , 0}$ & 1,4 & $\mathbf{2 , 6}$ & 1,5 & $\mathbf{3 , 4}$ & 0,6 & 0,6 \\
\hline Węgry & 2,2 & $\mathbf{3 , 8}$ & 1,8 & $\mathbf{4 , 1}$ & 0,1 & $\mathbf{0 , 2}$ & 2,8 & $\mathbf{3 , 5}$ & 0,5 & 0,3 \\
\hline Polska & 1,5 & $\mathbf{2 , 8}$ & 3,3 & 1,2 & 14,6 & 8,1 & 7,3 & $\mathbf{7 , 4}$ & 1,2 & $\mathbf{1 , 3}$ \\
\hline Słowacja & 1,7 & $\mathbf{3 , 1}$ & 3,2 & 1,1 & 1,1 & $\mathbf{1 , 3}$ & 7,6 & $\mathbf{9 , 0}$ & 0,7 & 0,6 \\
\hline Słowenia & 0,3 & $\mathbf{0 , 6}$ & 3,8 & 1,7 & 0,6 & 0,6 & 6,8 & $\mathbf{7 , 5}$ & 0,7 & 0,5 \\
\hline Rumunia & 0,5 & $\mathbf{3 , 9}$ & 4,9 & 3,4 & 7,7 & 2,9 & 7,1 & $\mathbf{8 , 7}$ & 2,7 & 2,1 \\
\hline Bułgaria & 0,0 & 0,0 & 0,8 & 0,7 & 4,2 & $\mathbf{7 , 5}$ & 4,3 & $\mathbf{6 , 4}$ & 0,7 & 0,4 \\
\hline Lotwa & 0,1 & $\mathbf{0 , 2}$ & 1,0 & 0,4 & 1,7 & $\mathbf{3 , 7}$ & 3,8 & 3,7 & 3,8 & 0,8 \\
\hline Litwa & 0,0 & 0,1 & 2,0 & 0,5 & 1,9 & b.d. & 1,9 & $\mathbf{2 , 0}$ & 1,2 & 0,9 \\
\hline \hline
\end{tabular}

W badaniu uwzględniono państwa będące w statystykach OECD-WTO. Podstawą do budowy GVCs były relatywne pozycje krajów w ramach danych gałęzi przemysłu.

Źródło: Obliczenia własne na podstawie danych TiVA OECD-WTO.

Należy mieć świadomość, iż przedstawione badanie cechuje się pewnymi ograniczeniami wynikającymi z dostępności danych statystycznych. W analizie GVCs uwzględniono okres do 2009 r., jednak należy mieć świadomość, iż od 2009 r. obserwowano niekorzystne trendy handlowe dla większości krajów UE, w tym Europy Środkowo-Wschodniej. Stąd analiza pozycji badanych UE-10 w GVCs powinna zostać rozszerzona o ten okres. Uwzględnienie tych ostatnich lat w badaniu, może zmienić wyniki pozycji krajów w GVCs.

\section{Podsumowanie}

Badanie pozycji UE-10 w GVCs prowadzi do następujących wniosków. Po pierwsze, stopień uczestnictwa analizowanych państw UE-10 w GVCs w pierwszych latach po akcesji pozostawał zróżnicowany. Bardziej zintegrowane z międzynarodowymi powiązaniami produkcyjnymi były kraje, które ściśle współpracowały z Europą Zachodnią,

${ }^{4}$ Jednak wiele czynników wpłynęło na pogorszenie tej pozycji. Chociażby rosnąca rola Chin w produkcji dóbr branży elektronicznej (Cieślik, 2012; Cieślik, 2015b). 
zwłaszcza rynkiem niemieckim ${ }^{5}$. Po drugie, znaczna część towarów eksportowanych z krajów UE-10 przechodziła przez GVCs w Europie Zachodniej. Po trzecie, eksporterzy z Europy Środkowej i Wschodniej plasowali się zwykle w dalszych segmentach produkcji w łańcuchach wartości od ich zachodnich partnerów. Po czwarte, niektóre kraje UE-10 po akcesji poprawiły swoje pozycje w GVCs w zakresie mniej zaawansowanych branż, natomiast w przypadku sektorów bardziej zaawansowanych - pozycja większości krajów pogorszyła się w porównaniu z okresem sprzed akcesji do UE.

Ostatecznie zaprezentowana analiza nie potwierdza jednoznacznie postawionej w artykule hipotezy, iż kraje poprawiły swoją pozycję w globalnych łańcuchach wartości. Uzyskane wyniki zarówno w badaniu na poziomie państw, jak i wybranych branż nie potwierdzają poruszania się krajów UE-10 w górę GVCs we wszystkich obszarach handlu zagranicznego.

Podsumowując, na skutek ścisłej integracji z UE rynki europejskich państw postsocjalistycznych przyłączyły się do łańcuchów wartości występujących w regionie. Pojawiły się coraz silniejsze powiązania pomiędzy analizowanymi państwami w zakresie handlu i przepływów kapitałowych, szczególnie w sektorach bardziej zaawansowanych technologicznie. UE szybko stała się najważniejszym partnerem handlowym i inwestycyjnym UE-10 i tym samym obserwuje się pewnego rodzaju uzależnienie analizowanych krajów od rynków „starej UE”. Chociaż akcesję państw postsocjalistycznych do struktur unijnych należy uznać za kamień milowy w procesie zmniejszania przepaści rozwojowej dzielącej te kraje od UE-15, to efektem negatywnym takich powiązań stała się podatność nowoprzyjętych członków na szoki przemysłowe i popytowe pochodzące ze strefy euro. Pomimo tego negatywnego aspektu, o którym analizowane kraje przekonały się dość szybko podczas obecnego kryzysu globalnego, w przyszłości należy spodziewać się kontynuacji modelu integracji z UE, szczególnie w zakresie GVCs. Jednakże procesy integracji w zakresie handlu zagranicznego będą prawdopodobnie przebiegały $\mathrm{z}$ różną intensywnością i nie zawsze będą wiązały się z przesuwaniem w górę w ramach GVCs.

\section{Bibliografia}

Cieślik E. (2012), Efekt smoka. Skutki ekspansji gospodarczej Chin po 1978 roku, Wydawnictwa Fachowe CeDeWu, Warszawa.

Cieślik E. (2015a), Kraje postsocjalistyczne w globalnych tańcuchach wartości, „Studia Ekonomiczne PAN INE", nr 85(2), s. 167-184.

Cieślik E. (2015b), Rozwój gospodarczy Chin od roku 1978 do kryzysu globalnego, Wydawnictwo Key Text, Warszawa.

Dicken P., Kelly P., Olds K. (2011), Chains and Networks, Territories and Scales: Towards a Relational Framework for Analysing the Global Economy, „Global Networks”, April, s. 89-112.

Feenstra R., Hanson G. (1999), The Impact of Outsourcing and High-Technology Capital on Wages: Estimates for the United States, 1979-1990, „The Quarterly Journal of Economics”, nr 114(3), s. 907-940.

IMF (2013), German-Central European Supply Chain-Cluster Report, IMF, Washington, D.C.

${ }^{5}$ Więcej na ten temat w (IMF, 2013). 
Iossifov P. (2014), Cross-Border Production Chains and Business Cycle Co-Movement between Central and Eastern European Countries and Euro Area Member States, „Working Paper Series", issue 1628.

Koopman R., Powers W., Wang Z., Wei S.-J. (2010), Give Credit Where Credit Is Due: Tracing Value Added in Global Production Chains, „NBER Working paper” 16426.

McKinsey (2013), A new dawn: Reigniting growth in Central and Eastern Europe, McKinsey Global Institute, bmw., http://www.mckinsey.com/.

OECD (2014), OECD.StatExtracts, http://stats. oecd.org World Input-Output Database, 2015. http:// www.wiod.org/new_site/home.htm.

World Input-Output Database, http://www.wiod.org/new_site/home.htm.

\section{Streszczenie}

Artykuł ma na celu ukazanie zmian w handlu zagranicznym i roli nowych państw członkowskich UE (UE-10) w globalnych łańcuchach wartości na tle procesów liberalizacyjnych i procesu integracji z Unią Europejską (UE). Przeprowadzone badanie ma na celu zweryfikowanie następującej hipotezy: pozycja nowych krajów członkowskich w globalnych łańcuchach wartości po akcesji do UE znacząco wzrosła. W opracowaniu skoncentrowano się na analizie powiązań handlowych przed przystapieniem do UE i kilka lat po tej akcesji. Artykuł koncentruje się na analizie wartości dodanej na poziomie krajów i branż. W celu utrzymania jednolitości i porównywalności otrzymanych wyników badań w opracowaniu posłużono się bazami danych organizacji międzynarodowych, głównie OECD-WTO Trade in Value Added oraz World InputOutput Database.

Słowa kluczowe: UE-10, wartość dodana, handel zagraniczny

\section{The participation of new EU member states (EU-10) in global value chains in the years immediately following their accession to the European Union}

\section{Summary}

The aim of this article is to analyse changes in foreign trade in the so-called new member states (EU-10) and the role these states play in global value chains (GVCs) as a result of liberalisation and integration with the EU. The hypothesis of this article is: the position in GVCs of analyzed states has improved significantly since the EU accession. The study focuses on trade linkages among countries before and after the accession. The article focuses on the country-level and sectoral-level value-added analysis. To ensure consistency and comparability of results, the data sources were databases kept by international organisations, mainly OECD-WTO Trade in Value Added and World Input-Output Database.

Key words: EU-10, value added, foreign trade 
